\title{
Development of sustainability indices for the wider area of Troodos in Cyprus
}

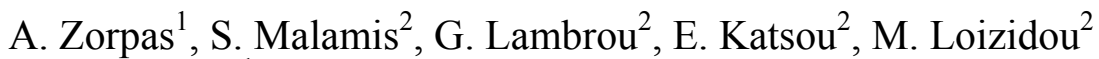 \\ \& I. Voukkali ${ }^{1}$ \\ ${ }^{1}$ Institute of Environmental Technology and Sustainable Development, \\ Cyprus \\ ${ }^{2}$ National Technical University of Athens, Department of Chemical \\ Engineering, Laboratory of Environmental Science, Greece
}

\begin{abstract}
The concept of sustainability gathers together the various elements contributing to a human life support system on Earth and follows the seminal approach established by the Brundtl and report on sustainable development. Traditionally, sustainability is associated with criteria such as efficiency or equity from an economic, social and environmental viewpoint and deals with intra-generational and intergenerational issues. Indicators are considered of crucial importance for the measurement of "sustainability" in local contexts as well as for national and international policies, as they allow communicating, discussing and taking decisions on complex facts and trends, using relatively few data. The paper describes the development of sustainable indices for the wider area of Troodos in Cyprus which include 100 villages (that belong to two districts: Nicosia and Limassol), according to five criteria, which are considered as essential components of sustainable indices for the Troodos' Mountains management. These criteria are: (i) society, (ii) cultural, (iii) economical and tourist (iv) geologic and hydrology (v) natural environment. The questionnaire's main targets are to investigate the five criteria in relation with the data present in Table 1 and in case anyone chooses to stay permanent in any community of the Troodos' region.
\end{abstract}

Keywords: Cyprus, Troodos mountains, sustainable indices and development. 


\section{Introduction}

Sustainable development and therefore sustainability are linked not only to the three-way relationship between the environmental, economic, and social pillars but also to the institutional dimension of sustainable development. Prominent interactions exist respectively between the environmental and economical dimensions regarding viability and between the economic and social dimensions denoting equity. Furthermore, the distinction is conventionally made between weak sustainability as opposed to strong sustainability, allowing for a description of different types of capital and a total stock perspective.

These types are natural capital, manufactured capital, human capital, social capital, and their substitutability determines the position held between weak sustainability and strong sustainability. Traditionally, sustainability is associated with criteria such as efficiency or equity from an economical, social and environmental viewpoint and deals with intergenerational and intergenerational issues. Nevertheless, this concept is difficult to seize and ambiguities arise [1]. Indicators are crucial instruments for understanding, communicating, and evaluating environmental processes and policies. They consist of data or parameters easy to understand, which are able to represent a more complex reality. If available for different years, the data can be aggregated to time series, creating indicators able to show trends. Indicators may consist either of single data which can be assumed to be a "key data", representing the state or a trend of environmental, economic or social conditions. For instance, in the field of pollution, the state of organisms particularly sensible to environmental changes can be used for indicating environmental changes. Within the set of indicators for the implementation of integrated coastal zone management, the surface of protected areas is used as an indicator for the state of protection of natural diversity. Indicators may also consist of more complex, constructed data as for instance the ratio between the population living in a coastal area and the value of residential properties, which may be used as an indicator for the demand of property on the coast.

Many works have been conducted by international organizations as well as by national agencies and governments in order to elaborate national sustainable development strategies. The aim has been to elaborate incentive tools for considering the multidimensional nature of sustainable development and for assessing related progress [2]. The United Nations Commission on Sustainable Development [3] led the way by implementing a work programme in April 1995 resulting in a first list of 134 indicators in 1996. After being tested in 22 countries in 2000, this list was reduced down to 59 so-called basic indicators for which a methodological guide was published in September 2001. From 1998, the OECD adopted the same approach based on an initial extensive list and several meetings among scientific experts until 2003, when a list of 69 reference indicators was published. EUROSTAT has employed a similar approach: a first test concerning the 134 United Nations indicators was carried out in 1997, and was then followed by the publication of list of 69 indicators derived from the basic United Nations indicators. After the Göteborg summit held in June 2001, a 
specific task-force resulted in a prioritized system consisting of 155 indicators which were validated in 2005: 12 so-called main indicators were to be used by high-ranking decision makers and a large public, 45 strategic indicators were related to sub-subjects, and finally, 98 so-called analytic indicators represented the various processes $[4,5]$. Even though indicators were initially elaborated from the sustainable development pillars (environmental, economic, social, and institutional issues), the interactions between these pillars are mostly favored by issues, thus enabling the introduction of values and priorities of relevant populations.

EU has thus recently drawn up guidelines and indicators concerning sustainable development whilst taking into account issues at stake [5]. The aim is to integrate knowledge and create transversal bridges in order to link pillars and to encourage the commitment of people. After their initial development at an international level, where sustainable development indicators essentially ensure a normative and educational function, these approaches were progressively implemented at other levels. They were then employed at national and local levels, where they were used for implementing sustainable management and decision support principles for managers. It is verified that interactions existing between the different pillars of sustainable development are best taken into account at a local scale where positive synergies between these dimensions are expressed most accurately.

Cyprus is situated in the north-eastern part of the Mediterranean Sea, 338 east and 358 north of the Equator. It is situated $75 \mathrm{~km}$ south of Turkey, $105 \mathrm{~km}$ west of Syria, $380 \mathrm{~km}$ north of Egypt, and $380 \mathrm{~km}$ east of Rhodes (Greece). The third largest Mediterranean island after Sicily and Sardinia, it has an area of $9251 \mathrm{~km}^{2}$, of which 1733 are forested. Cyprus has a record of successful economic performance, reflected in rapid growth, full employment conditions and external and internal stability, almost throughout the post-Independence period. The underdeveloped economy, inherited from colonial rule until 1960, has been transformed into a viable economy with dynamic services, industrial and agricultural sectors and advanced physical and social infrastructure. In terms of per capita income, is currently estimated at US \$13000 during 2000 and at US \$ 20000 during 2008, it is classified as the highest income country of all the entering new EU members.

The research deals with the development of the sustainable indicators in relation with the scenario that anyone chooses to stay permanent in any Community of the Troodos' region in Cyprus according to several criteria as followed, because most young people have left from the villages in the mountains.

\section{Description of the selected area: methodology}

Troodos is the biggest mountain range of Cyprus, located in the centre of the Island. Troodos' highest peak is Mount Olympus at 1952 metres (Figures 1 and 2). Troodos' mountain range stretches across most of the western side of Cyprus. There are many famous mountain resorts, Byzantine monasteries and churches on mountain peaks, and nestling in its valleys and picturesque 

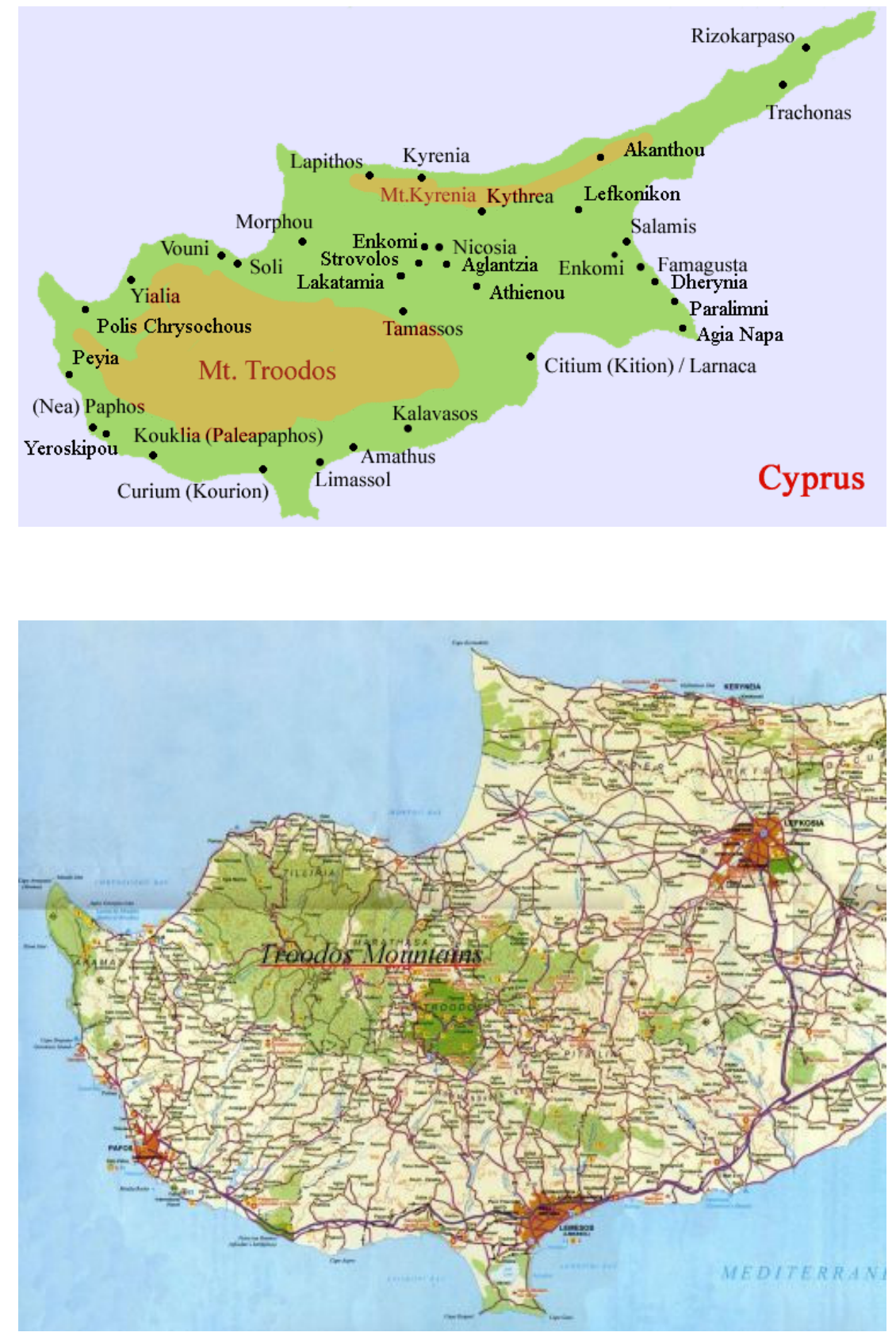

Figure 1: $\quad$ Map of Cyprus. 

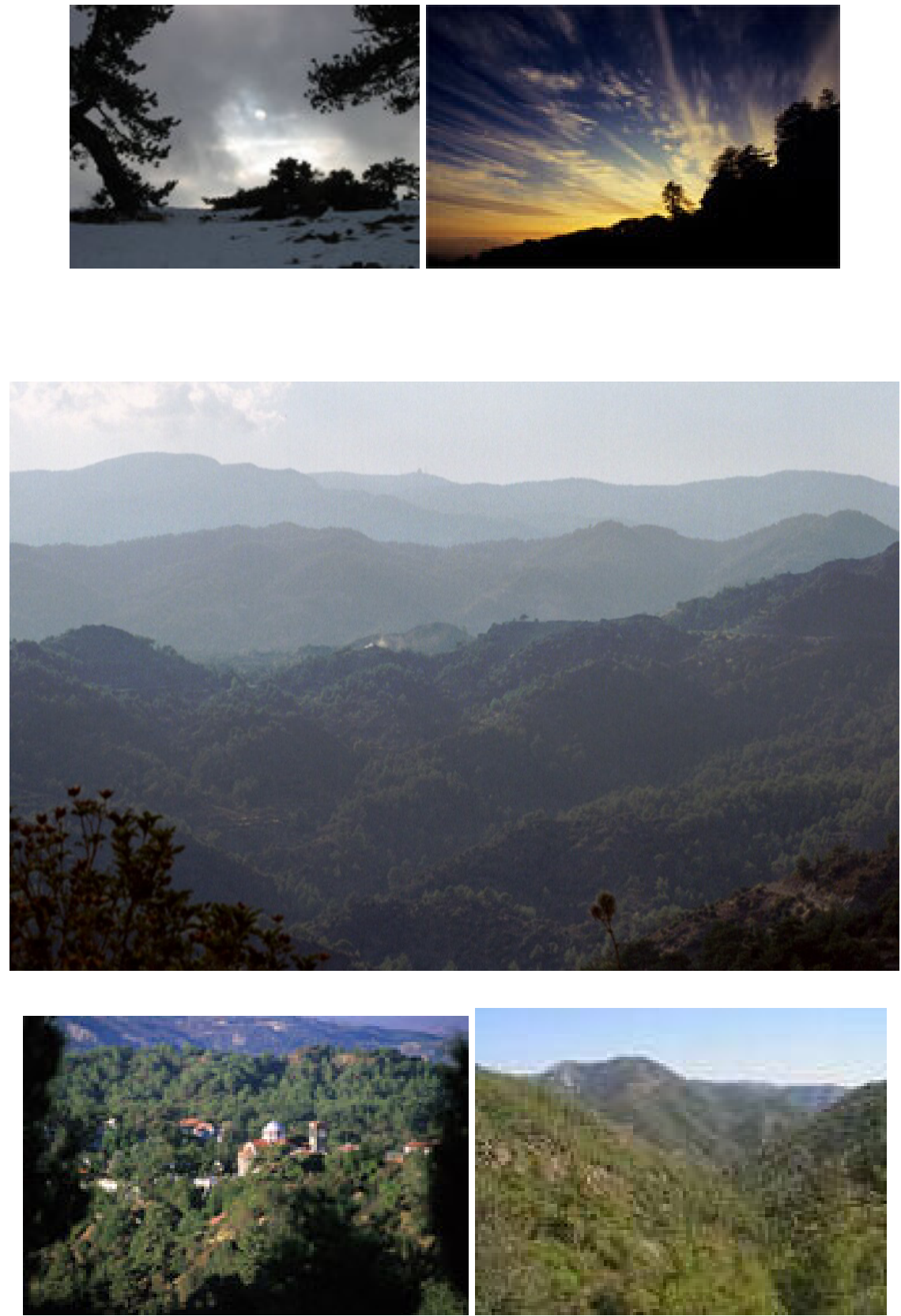

Figure 2: $\quad$ Panoramic view of Troodos Mountains. 
mountain villages clinging to terraced hill slopes. There are nine churches and one monastery in Troodos that are counted among UNESCOs Word Heritage Sites and several other monasteries, of which the Kykkos monastery is the richest and most famous. The nine Byzantine churches are: Stavros tou Ayiasmati, Panayia tou Araka, Timiou Stavrou at Pelendri, Ayios Nikolaos tis Stegis, Panayia Podithou, Assinou, Ayios loannis Lampadistis, Panayia tou Moutoula, Archangel Michael at Pedhoulas. The area has been known since the ancient times for its copper mines, and in the Byzantine period became a great centre of Byzantine art, as churches and monasteries were built in the mountains, away from the threatened coastline. During the second half of the 20th century most young people have left the villages in the mountains, but efforts have been made to establish the region as a tourist resort.

The paper describes the development of sustainable indices for the wider area of Troodos in Cyprus, which include 100 villages (that belong in two districts: Nicosias and Limassol), according to five criteria, which are considered as essential components of sustainable indices for the Troodos Mountains management.

These criteria are: (A) society, (B) cultural, (C) economical and tourist (D) geologic and hydrology (E) natural environment. Those criteria are divided into several categories as indicated in table 1 and the Troodos area has been divided into 7 regions as follows: R1: North Pitsilia (20 villages Nicosia), R2: South Pitsilia (10 villages Limassol), R3: Marathasa (8 villages Nicosia, 6 villages Limassol), R4: Solea (13 villages Nicosia), R5: Wineries (23 villages Limassol), R6: villages producing Koumantaria (12 villages Nicosia) and R7: Troodos (8 villages Limassol).

According to the Statistic Services in Cyprus (2004) the total population of the 100 villages in the Troodos area is 23,768 inhabitants with the biggest village to be Kyperounta with 1497 inhabitants (belonging to the South Pitsilia Area), followed by Kakopetria with 1198 inhabitants (belonging to the Solea Area), while the smaller villages are Fikardou with 3 inhabitants (belonging to North Pitsilia) followed by Kissousa and Koukka with 4 inhabitants (belonging to Wineries Village) and Kourdas with 10 inhabitants (belonging to the Solea area).

In order to estimate the stress coefficient of the above 5 criteria a questionnaire has been developed in order to examine the significant of each criteria according to the above data presented in Table 1. Questionnaire credits were from 0 to 10 with zero to be the worst and 10 the best credit. The questionnaire's main targets are to investigate those five criteria in relation with the data presented in Table 1 and with the scenario that anyone chooses to stay permanent in any Community of the Troodos' region. The questionnaire has been completed by several people and aged 17-50 and from several cultural levels.

In order to estimate the indices, the Performance Ordering Method (PROMETHEE) has been applied using the Decision Lab 2000. Decision Lab is a multi-criteria analysis and decision-making software. Its advanced features will provide evidence of strengths against weaknesses, of conflicts and consensus. 
Table 1: $\quad$ Investigated indicators per each criterion.

\begin{tabular}{|c|c|c|c|c|c|}
\hline Indicators & $\begin{array}{l}\text { Society } \\
\text { (A) }\end{array}$ & Cultural (B) & $\begin{array}{c}\text { Economical } \\
\text { and tourist }(\mathrm{C})\end{array}$ & $\begin{array}{c}\text { Geologic and } \\
\text { hydrology (D) }\end{array}$ & $\begin{array}{c}\text { Natural } \\
\text { environment (E) }\end{array}$ \\
\hline 1 & Population & $\begin{array}{c}\text { Community } \\
\text { structural }\end{array}$ & Jobs & Rivers & $\begin{array}{l}\text { Forest areas } \\
\text { Parks }\end{array}$ \\
\hline 2 & Ages (ever ages) & $\begin{array}{c}\text { Entertainment, } \\
\text { traditional } \\
\text { festivals, music, } \\
\text { etc }\end{array}$ & Quarries & Dam & Tour areas \\
\hline 3 & $\begin{array}{c}\text { Community per } \\
\text { area }\end{array}$ & $\begin{array}{l}\text { Unesco } \\
\text { memorial }\end{array}$ & $\begin{array}{l}\text { Hotels and } \\
\text { hostels }\end{array}$ & Biotope & Natura 2000 area \\
\hline 4 & Education level & $\begin{array}{c}\text { Archaeological } \\
\text { areas }\end{array}$ & $\begin{array}{l}\text { Agro tourist } \\
\text { facilities }\end{array}$ & Geomorphology & Natural footpath \\
\hline 5 & $\begin{array}{c}\text { School, nursing } \\
\text { home, } \\
\text { community } \\
\text { clinic, etc }\end{array}$ & $\begin{array}{c}\text { Other } \\
\text { memorials }\end{array}$ & Camps areas & Falls & Cycling \\
\hline 6 & $\begin{array}{l}\text { Distance from } \\
\text { town }\end{array}$ & Museum & Congress rooms & Natural Spring & $\begin{array}{c}\text { Essence of } \\
\text { Landfill sites }\end{array}$ \\
\hline 7 & --- & Athletic place & Restaurants & Natural Spa & Waste water plants \\
\hline 8 & $\begin{array}{ll}-- \\
\end{array}$ & $\begin{array}{l}\text { Churches not } \\
\text { included in } \\
\text { UNESCO }\end{array}$ & $\begin{array}{c}\text { Tourist Services } \\
\text { (information, } \\
\text { guides) }\end{array}$ & Area elevation & --- \\
\hline 9 & --- & Internet & --- & --- & --- \\
\hline
\end{tabular}

With the several "What if?" scenarios, will really improve the quality and the reliability of the decision-making processes.

\section{Result and discussions}

Table 2 presents the stress coefficient of the above 5 criteria and the stress coefficient per Indicator according to the results given by the Decision Lab. Table 3 presents the inhabitants' repartition per age and region. This criterion (population ages) is very important as young people abandon the countryside. Table 4 presents the calibration of Criteria A-E in relation to the regions R1-R7. For the A4 criterion (Education Level) $60 \%$ of the total population seems to be also an important issue as, according to the questionnaire analysis, and the Statistical Services in Cyprus, they have finished the gymnasium, 30\% has graduated high school while $10 \%$ has a University degree. According to the same source the R1 has 9, R2 has 11, R3 has 10, R4 has 12, R5 has 9, R6 has 4 while R7 has 7 utility services (including schools, nursing home, community clinic). Distances are not so important as the major distance from the centre of the closer Town (Nicosia or Limassol) is from $18-50 \mathrm{Km}$ in proportion of the village.

Each community presented with significant structure in order to solve their own problems. All communities presented with voluntary teams (B2). Universal memorial as described by UNESCO there are a lot in the Troodos Area and this indicator is examined in order to find out if is useful for the development of the area. This indicator (B3) seems to be useful for the region R1, R3, and R4. As 
Table 2: Percentage of stress coefficient per each criterion and stress coefficient per indicator.

\begin{tabular}{c|c|c|c|c|c|c|c|c|c|c}
\hline \multirow{2}{*}{\begin{tabular}{c} 
Cri $\begin{array}{c}\text { ter } \\
\text { ion }\end{array}$ \\
\cline { 2 - 12 }
\end{tabular}} & 1 & 2 & 3 & 4 & 5 & 6 & 7 & 8 & 9 & \\
\hline $\mathrm{A}$ & 0.033 & 0.033 & 0.029 & 0.033 & 0.042 & 0.037 & --- & --- & --- & 21 \\
\hline $\mathrm{B}$ & 0.025 & 0.021 & 0.016 & 0.016 & 0.016 & 0.016 & 0.021 & 0.018 & 0.028 & 18 \\
\hline $\mathrm{C}$ & 0.027 & 0.014 & 0.023 & 0.021 & 0.021 & 0.021 & 0.027 & 0.023 & --- & 18 \\
\hline $\mathrm{D}$ & 0.025 & 0.021 & 0.021 & 0.021 & 0.021 & 0.027 & 0.019 & 0.021 & --- & 18 \\
\hline $\mathrm{E}$ & 0.045 & 0.037 & 0.032 & 0.037 & 0.032 & 0.032 & 0.032 & --- & --- & 25 \\
\hline
\end{tabular}

Table 3: Inhabitants repartition per age and region.

\begin{tabular}{c|c|c|c|c|c}
\hline \multirow{2}{*}{ Region } & \multicolumn{5}{|c}{ Ages (years) } \\
\cline { 2 - 6 } & $0-14$ & $15-29$ & $30-44$ & $45-64$ & +65 \\
\hline North Pitsilia & 628 & 701 & 579 & 858 & 985 \\
\hline South Pitsilia & 875 & 782 & 711 & 1113 & 1163 \\
\hline Marathasa & 223 & 281 & 224 & 515 & 902 \\
\hline Solea & 773 & 994 & 724 & 1336 & 1186 \\
\hline Wineries & 695 & 695 & 613 & 118 & 1335 \\
\hline Koumantaria & 354 & 330 & 350 & 561 & 502 \\
\hline Troodos & 188 & 168 & 196 & 382 & 439 \\
\hline
\end{tabular}

the Tourist Activities are the mainly heavy product for Cyprus is also influencing the impact of those Regions. However, in order to be a destination attractive to tourism, it must first promote the beauty, the priorities and the facilities of the area. Criterion $\mathrm{C}$ aims to investigate the relation between economic activities and tourism. The most important issues of this were that R3, R5, and R7 presented with excellent tourist facilities including restaurants, conference rooms, events, which help the economics of the area.

Even though Cyprus has been known worldwide for cooper mining, those are producing either jobs positions and also significant environmental problems. This indices $\mathrm{C} 2$ shows the impact of the queries and mining on the environment. R7 is the region with the most queries and mining consisting of negative environmental impacts.

A significant indicator is also the geological and hydrological characteristics of the area as Cyprus is presented with scarcity of water. All the examined Regions (R1-R7) are developed close to the watershed. Water is a very important resource for success in developing an area. However, Cyprus presents with four small waterfalls and all of them are found in the R7 region. R4 and R7 are the only regions without any dam. Hence, R7 is the most inaccessible area due to its natural geological characteristics but all regions from R1 to R7 presented with natural sources while the R3 is the region with the most natural spa (four). The elevation of each region seems not to present negative impact due to the very organized road net. 
Table 4: $\quad$ Calibration of Criteria A-E for regions R1-R7.

\begin{tabular}{|c|c|c|c|c|c|c|c|}
\hline \multirow{2}{*}{$\begin{array}{c}\text { Criterion } \\
\text { as } \\
\text { described } \\
\text { above }\end{array}$} & \multicolumn{7}{|c|}{ Regions as described above } \\
\hline & R1 & $\mathrm{R} 2$ & $\mathrm{R} 3$ & R4 & R5 & R6 & R7 \\
\hline A1 & 6 & 8 & 4 & 10 & 8 & 4 & 2 \\
\hline A2 & 7 & 8 & 4 & 10 & 8 & 5 & 3 \\
\hline A3 & 8 & 6 & 8 & 8 & 10 & 6 & 4 \\
\hline A4 & 6 & 8 & 4 & 10 & 8 & 4 & 2 \\
\hline A5 & 8 & 10 & 8 & 10 & 8 & 2 & 4 \\
\hline A6 & 6 & 2 & 8 & 7 & 2 & 1 & 10 \\
\hline B1 & 6 & 3 & 4 & 5 & 7 & 3 & 2 \\
\hline B2 & 7 & 6 & 6 & 5 & 8 & 1 & 2 \\
\hline B3 & 10 & 5 & 10 & 10 & 1 & 1 & 1 \\
\hline B4 & 9 & 4 & 4 & 10 & 6 & 4 & 6 \\
\hline B5 & 7 & 10 & 4 & 8 & 4 & 2 & 7 \\
\hline B6 & 3 & 7 & 4 & 3 & 10 & 3 & 2 \\
\hline B7 & 2 & 9 & 4 & 10 & 3 & 1 & 5 \\
\hline B8 & 7 & 5 & 10 & 9 & 9 & 5 & 6 \\
\hline B9 & 10 & 1 & 1 & 10 & 1 & 10 & 1 \\
\hline $\mathrm{C} 1$ & 6 & 5 & 10 & 4 & 5 & 9 & 10 \\
\hline $\mathrm{C} 2$ & 5 & 1 & 1 & 5 & 1 & 1 & 10 \\
\hline C3 & 1 & 2 & 8 & 7 & 1 & 1 & 10 \\
\hline $\mathrm{C} 4$ & 4 & 1 & 5 & 4 & 10 & 1 & 1 \\
\hline C5 & 2 & 3 & 5 & 3 & 1 & 2 & 10 \\
\hline C6 & 2 & 7 & 2 & 4 & 2 & 1 & 10 \\
\hline C7 & 2 & 3 & 5 & 10 & 7 & 2 & 10 \\
\hline C8 & 1 & 2 & 1 & 2 & 1 & 1 & 1 \\
\hline D1 & 8 & 6 & 10 & 4 & 6 & 4 & 10 \\
\hline D2 & 5 & 5 & 10 & 1 & 5 & 5 & 1 \\
\hline D3 & 3 & 2 & 6 & 2 & 3 & 3 & 6 \\
\hline $\mathrm{D} 4$ & 8 & 8 & 7 & 8 & 6 & 6 & 10 \\
\hline D5 & 1 & 1 & 1 & 1 & 1 & 1 & 10 \\
\hline D6 & 10 & 10 & 10 & 10 & 9 & 9 & 10 \\
\hline D7 & 1 & 5 & 10 & 1 & 1 & 1 & 3 \\
\hline D8 & 8 & 8 & 9 & 8 & 7 & 6 & 10 \\
\hline E1 & 10 & 1 & 9 & 8 & 4 & 2 & 10 \\
\hline E2 & 3 & 4 & 10 & 2 & 1 & 1 & 7 \\
\hline E3 & 6 & 1 & 4 & 2 & 6 & 6 & 10 \\
\hline E4 & 10 & 5 & 4 & 4 & 2 & 1 & 10 \\
\hline E5 & 10 & 1 & 10 & 10 & 1 & 1 & 10 \\
\hline E6 & 3 & 6 & 4 & 8 & 10 & 3 & 1 \\
\hline E7 & 8 & 10 & 1 & 4 & 4 & 1 & 1 \\
\hline
\end{tabular}


Environmental Indicators showed that Cyprus forest presented with important fauna and flora. Tours space and Natura 2000 areas according to the 92/43/EC and 79/409/EC directives retain the ecological landscape and also the fauna and flora of the selected regions. Regions with Natura 2000 decrease any development in any area. A negative environmental indicator is the illegal landfill side with R5 to be in the top of the list. Wastewater treatment plants are a positive issue and R2 is presented in the top of the list with 3 treatment plants.

\section{Conclusions}

Figure 3 presents the Indicators Profile according to the results of Decision Lab per Indicator $(\mathrm{A}, \mathrm{B}, \mathrm{C}, \mathrm{D}, \mathrm{E})$ and per Region (R1-R7). R1 presented with a good

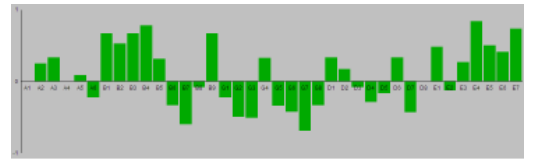

R1

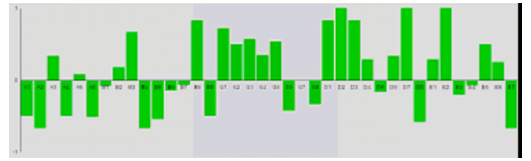

R3

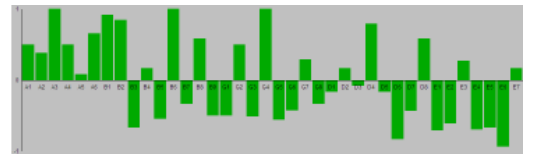

R5

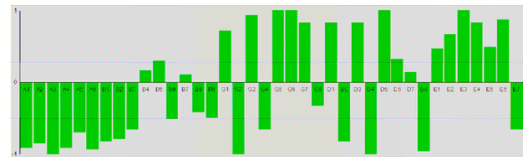

R7

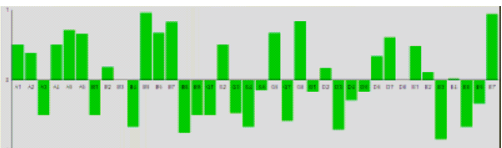

R2

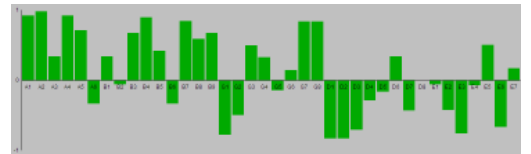

R4

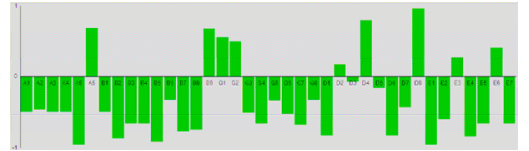

R6

Figure 3: Indicators Profile according to the results of Decision Lab per Indicator $(\mathrm{A}, \mathrm{B}, \mathrm{C}, \mathrm{D}, \mathrm{E})$ in relation with Region (R1-R7).

profile for the Cultural and Environmental Indices and less for economics and tourism. R3 presented with good economical and tourist indices and with less for geological and hydrological. R4 presented with good social and cultures indices and were inferior in the geologic and hydrologic indices.

R3, R1 and R4 presented as the most developed areas, with R4 having all the schools that one area needs to be developed. The less developed area is region R6 which has been deserted

From the sensitive analysis of each indicator in relation with which indicator is more significant per region we have several results. Regardless of which 
indicators are more significant, the result remains the same for R1, R3 and R4 but with reverse order per examined indicator.

The most significant result from the sensitive analysis is that the region R7 must be protected from any environmental issue.

Concluding, it can be said that the development of all the examined areas is feasible and region $\mathrm{R} 4$ can be a model.

The answer to our questions is that any one can stay permanently in any community and this has to do with what standards are implemented.

\section{References}

[1] Roussel, S.; Crinquant, N. and Bourdat, E. (2007), "In search of coastal zone sustainability by means of social carrying capacity indicators construction: lessons learned from the Thau lagoon case study (Région LanguedocRoussillon, France)", International Journal of Sustainable Development, 10 (1/2): 175-194.

[2] Rey-Valette, H.; Damart, S. and Roussel, S., "A multicriteria participationbased methodology for selecting sustainable development indicators: an incentive tool for concerted decision making beyond the diagnosis framework", International Journal of Sustainable Development, 10 (1/2): 122-138

[3] UNCSD United Nations Commission on Sustainable Development

[4] Zuintnen, N. (2004), "Indicateurs pour un développement durable : aspects méthodologiques et développements en cours", Working Paper No. 4-04 of the Bureau Fédéral du Plan, Brussels, Belgium.

[5] EUROSTAT (2005), "Measuring progress towards a more sustainable Europe, sustainable development indicators for the European Union", Luxembourg: Office for official publications of the European Communities. 